\title{
ALDEHYDE EMISSIONS FROM AN ETHANOL-FUELLED SPARK IGNITION ENGINE: SIMULATION AND FTIR MEASUREMENTS
}

\author{
P. B. ZARANTE ${ }^{1}$, T. COSTA $^{2}$ e J. R. SODRÉ ${ }^{3}$ \\ ${ }^{1}$ Universidad del Atlántico, Department of Mechanical Engineering \\ ${ }^{2}$ FIAT Chrysler Latin America, Vehicle Testing Division \\ ${ }^{3}$ Pontifical Catholic University of Minas Gerais, Department of Mechanical Engineering \\ Contact e-mail: ricardo@ pucminas.br
}

\begin{abstract}
This paper presents a mathematical model which calculates aldehyde emissions in the exhaust of a spark ignition engine fueled with ethanol. The numerical model for aldehyde emissions was developed using FORTRAN software, with input data obtained from the engine cycle simulated by the commercial software BOOST. The model calculates formaldehyde and acetaldehyde emissions, formed from the partial oxidation of methane, ethane and unburned ethanol. The calculated values were compared with experimental data obtained by Fourier Transform Infrared Spectroscopy (FTIR). Tests were performed with a mid-size sedan powered by 1.4liter spark ignition engine on a chassis dynamometer. In general, the results demonstrate that the concentrations of aldehydes and their producers increased with engine speed and exhaust gas temperature. There was a good agreement between simulated and measured values.
\end{abstract}

\section{INTRODUCTION}

In response to the increased fossil fuel demand and the implications of the generated pollutant emissions, research related to alternatives to fossil fuels have ever gained importance. In general, the emissions from alternative fuels are less reactive and toxic, resulting in reduced production of ozone and improved air quality (Nguyen et al., 2001). These emissions are classified as regulated pollutants such as oxides of nitrogen (NOX), carbon monoxide (CO), hydrocarbons (HC) and particulate matter (PM), and unregulated pollutants, including aldehydes (RCHO), benzene, toluene, xylene (BTX), sulfur dioxide $\left(\mathrm{SO}_{2}\right)$, etc. (Merrit et al., 2005).

Ethanol is an attractive alternative fuel for use in spark-ignition engines, from the viewpoint of regulated emissions, ethanol is a clean fuel. The addition of ethanol to gasoline improves fuel economy and reduces emissions of $\mathrm{CO}, \mathrm{HC}$ and $\mathrm{NOX}$ from spark ignition engines (Keating, 1993). However, the incomplete combustion of the ethyl alcohol in the exhaust of internal combustion engines releases high concentrations of aldehydes (RCHO). Aldehydes are highly reactive organic compounds that participate in complex chemical 


\section{9 a 22 de outubro de 2014 \\ Florianópolis/SC}

reactions in the atmosphere. Only aldehydes encountered in the gaseous state are considered pollutants in internal combustion engines: formaldehyde $\left(\mathrm{CH}_{2} \mathrm{O}\right)$ and acetaldehyde $\left(\mathrm{C}_{2} \mathrm{H}_{4} \mathrm{O}\right)$. The emissions of aldehydes are higher for ethanol fuel due to the presence of the hydroxyl functional group $(\mathrm{OH})$, absent in gasoline (Basshuysen et al. 2004).

In order to describe the chemical reactions occurring during ethanol combustion, detailed kinetic models were developed by authors such as Marinov (1998), Li et al. (2007), Frassoldati et al. (2010) and Dauster (2010). These models simulate the chemical reactions within reactors used for combustion studies. However, these models exhibit great chemical complexity, requiring several hundreds of reactions to obtain the results.

The paper describes a model of formaldehyde and acetaldehyde formation in the engine exhaust from methane, ethane and unburned ethanol oxidation, formed as intermediate products of ethanol combustion. The chemical kinetic model developed by Costa et al. (2013) presents aldehyde formation in internal combustion engines fueled by gasoline or ethanol and it was taken as a basis for this work. The results from the simulation are compared with experimental data obtained from a production vehicle tested in laboratory, with exhaust formaldehyde and acetaldehyde being measured by the Fourier Transform Infrared (FTIR) technique.

\section{SIMULATION MODEL}

The commercially available BOOST software is used to simulate the cycle of the internal combustion engine. The BOOST software is not able to calculate aldehyde emissions. A fourstroke spark ignition engine operating with ethanol as fuel is considered in the simulation. The calculated temperature and pressure history along the cycle and the exhaust concentration of oxygen and unburned ethanol are used as input data for the aldehyde emissions model here developed in FORTRAN code. The methodology used to simulate formaldehyde and acetaldehyde formation is based on the theory of chemical reaction kinetics applied to aldehyde formation after ethanol combustion inside the cylinder. The aldehyde formation reactions start in the cylinder and propagate through the exhaust pipe. The differential equations of the chemical reactions within the cylinder and the exhaust pipe are time-integrated, obtaining algebraic expressions for the concentrations of formaldehyde, acetaldehyde, methane and ethane.

The aldehyde simulation model considers that exhaust acetaldehyde $\left(\mathrm{CH}_{3} \mathrm{CHO}\right)$ is mainly formed in the intermediate phase of the post-flame oxidation of unburned ethanol $\left(\mathrm{CH}_{3} \mathrm{CH}_{2} \mathrm{OH}\right)$ in the combustion chamber and in the exhaust pipe, according to Equation (1).

$$
\mathrm{CH}_{3} \mathrm{CH}_{2} \mathrm{OH}+[\mathrm{O}] \rightarrow \mathrm{CH}_{3} \mathrm{CHO}+\mathrm{H}_{2} \mathrm{O}
$$

Formaldehyde and acetaldehyde are also formed from the post-flame oxidation process of methane $\left(\mathrm{CH}_{4}\right)$ and ethane $\left(\mathrm{C}_{2} \mathrm{H}_{6}\right)$, respectively. These components are generated when the decomposition process of the unburned fuel in the exhaust gas is stopped at an intermediate stage of the chemical reaction. The interruption is mainly due to reduction of temperature and 
oxygen concentration. The first product of methane oxidation is methanol, which is immediately oxidized to formaldehyde in the presence of oxygen remaining in the general reaction as seen in Equation (2).

$$
\mathrm{CH}_{4}+\mathrm{O}_{2} \rightarrow \mathrm{CH}_{2} \mathrm{O}+\mathrm{H}_{2} \mathrm{O}
$$

The production of acetaldehyde from ethane oxidation is given by Equation (3).

$$
\mathrm{C}_{2} \mathrm{H}_{6}+\mathrm{O}_{2} \rightarrow \mathrm{C}_{2} \mathrm{H}_{4} \mathrm{O}+\mathrm{H}_{2} \mathrm{O}
$$

The aldehydes formed in the intermediate stages of the combustion process are immediately consumed by the flame front due to the high temperature attained in the combustion chamber. In order to calculate exhaust aldehyde concentration the oxidation reactions are considered separately, being the final concentration given by the sum of the parts produced in each reaction. Aldehyde formation is calculated from the combustion chamber to the sampling point in the exhaust pipe. While the concentration of unburned ethanol is given by the BOOST software, the concentrations of methane, ethane, formaldehyde and acetaldehyde are calculated by the aldehyde emission model from the reaction equations presented by Marinov (1998) and Costa et al., (2013). The calculation is performed from the moment the exhaust valve opens until the end of the exhaust process. Table 1 summarizes the equations used to calculate the concentrations of the exhaust gas components as a function of exposure time $(\mathrm{t})$, temperature $(\mathrm{T})$ and unburned ethanol concentration. Here, $\mathrm{n}_{\text {tot }}$ is the gas total number of moles, $\mathrm{R}$ is the universal gas constant, and $\mathrm{V}_{\text {cyl }}$ is the cylinder volume.

Table 1 - Main equations used to calculate formaldehyde and acetaldehyde emissions.

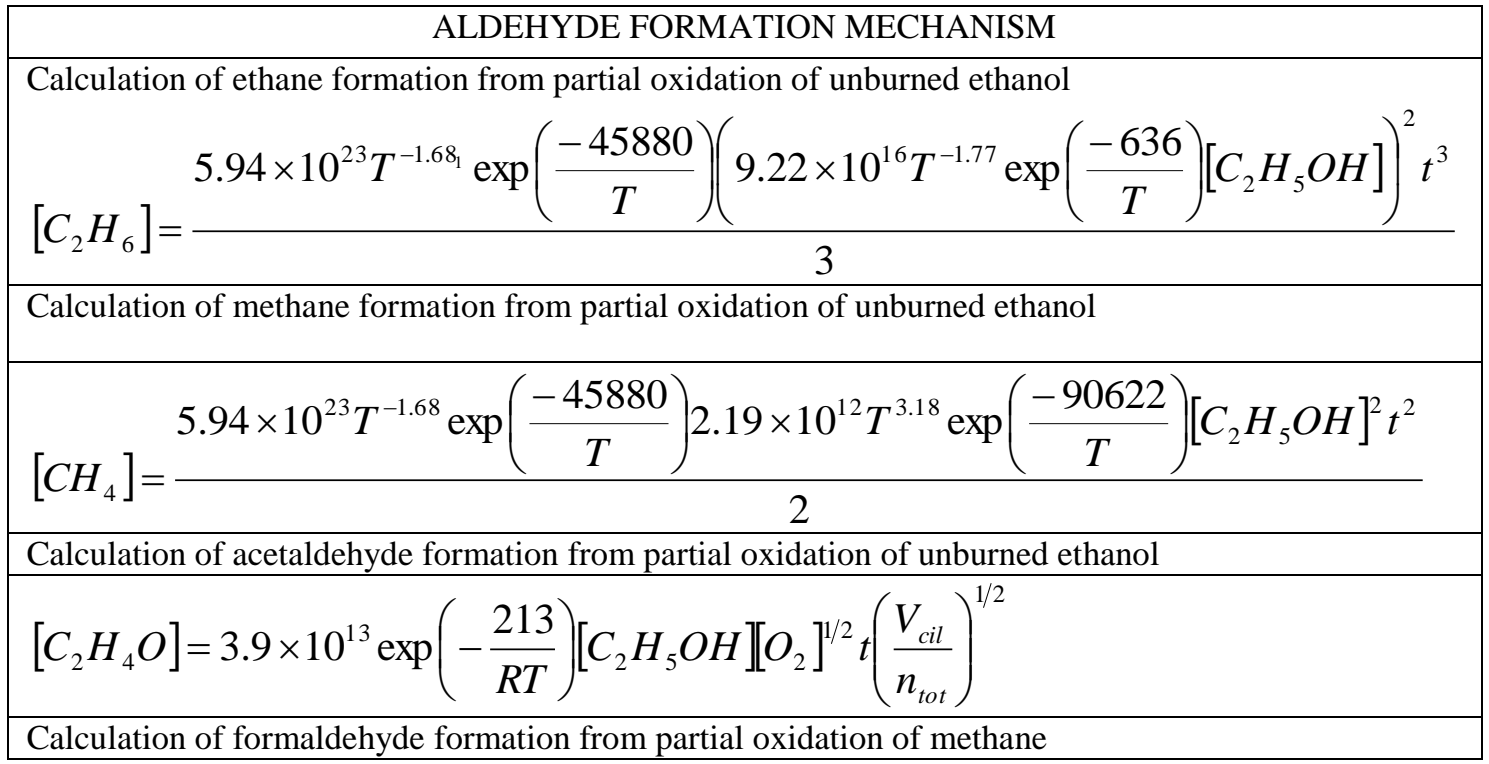




\begin{tabular}{|l|}
\hline$\left[\mathrm{CH}_{2} \mathrm{O}\right]=\frac{6.4 \times 10^{14} \exp \left(-\frac{179.9}{R T}\right) 3 \times 10^{13} \exp \left(-\frac{108.9}{R T}\right)\left[\mathrm{CH}_{4}\right]\left[\mathrm{O}_{2}\right] \mathrm{t}^{2}}{2}$ \\
\hline Calculation of acetaldehyde formation from partial oxidation of ethane \\
{$\left[\mathrm{C}_{2} \mathrm{H}_{4} \mathrm{O}\right]=\frac{3.9 \times 10^{13} \exp \left(-\frac{213}{R T}\right) 1.12 \times 10^{13} \exp \left(-\frac{127.3}{R T}\right)\left[\mathrm{C}_{2} \mathrm{H}_{6}\right]\left[\mathrm{O}_{2}\right] \mathrm{t}^{2}}{2}$} \\
\hline
\end{tabular}

\section{MODEL VALIDATION}

The model was validated against experimental data obtained from a 1.4-liter, fourcylinder spark ignition engine with compression ratio of 10.35:1, of $60 \mathrm{~kW}$ maximum power and 121 N.m maximum torque. The engine was operated in a bench test dynamometer at crankshaft speeds of 2000, 3000 and $4000 \mathrm{rpm}$ with wide open throttle and varying load, fuelled with hydrous ethanol (6.8\% wt./wt. of water). K-type thermocouples, with uncertainty of reading of $\pm 2{ }^{\circ} \mathrm{C}$, were installed in the engine to measure the intake air temperature and the exhaust gas temperature. The exhaust gas sample was taken from the exhaust pipe, close to the exhaust port, and driven through a heated sample line into a Fourier Transform Infrared (FTIR) analyzer. The exhaust gas was sampled at the rate of $1 \mathrm{~Hz}$ during three minutes at each engine operating condition. The measurements were made with the engine operating at steady state condition for a given speed and load setting. The results shown in the following section are the average of three tests performed at each engine operating condition.

\section{RESULTS AND DISCUSSION}

The trends shown by all substances present an increase of concentration with increasing engine speed and exhaust gas temperature as can be seen in Figure 1 to 5. Model and experiments generally show qualitative agreement, while the proximity of the quantitative values depends on the engine operating condition.

The results obtained for formaldehyde and acetaldehyde shown in Figures 1 and 2 are in agreement with the works by Amaral and Sodré $(2001,2002)$ and Pang et al. (2008), who also found increased aldehyde concentration with engine speed. It is observed that the concentrations of measured and simulated acetaldehyde are larger than those of formaldehyde, as found by Amaral and Sodré (2002), using ethanol as fuel, and by Pang et al. (2008), He et al. (2003), Song et al. (2010) and Magnusson et al. (2011), for ethanol blends.

The trend obtained for methane by FTIR analysis as observed in Figure 3, is not the same as that found for the measured formaldehyde from Figure 1, of which methane is the main producer. However, the simulated trends of methane and formaldehyde are similar. The simulated and measured values of ethane have a close resemblance presented in Figure 4. From Figures 3 and 4 exhaust methane concentration is higher than ethane concentration. 


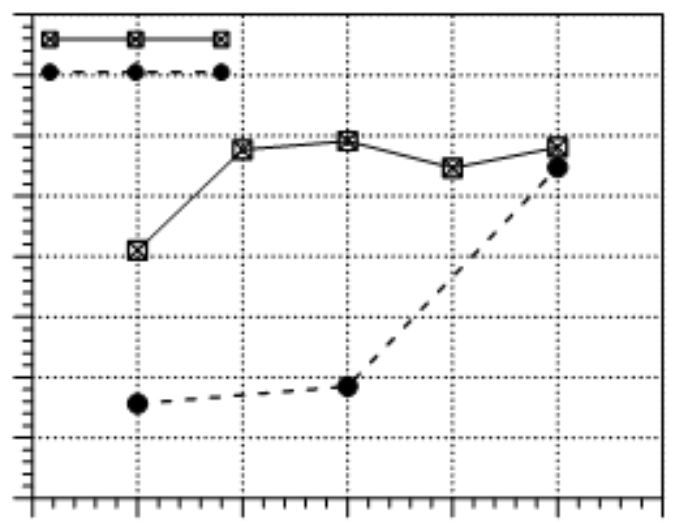

Figure 1 - Simulated and measured (FTIR) concentrations of exhaust formaldehyde.

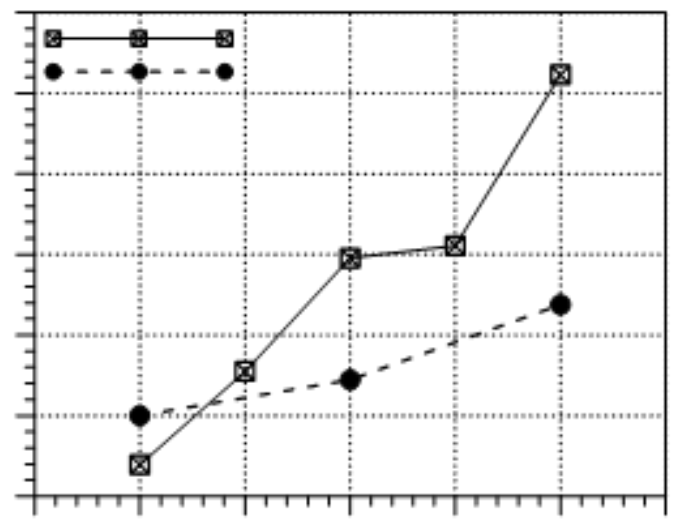

Figure 2 - Simulated and measured (FTIR) concentrations of exhaust formaldehyde.

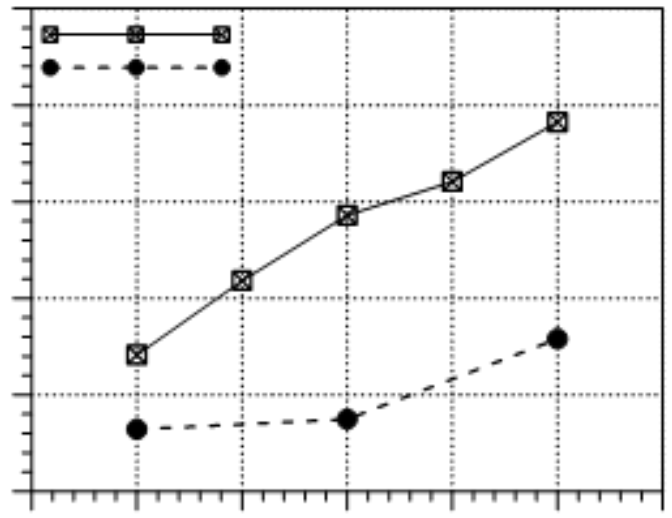

Figure 3 - Simulated and measured (FTIR) concentrations of exhaust methane. 


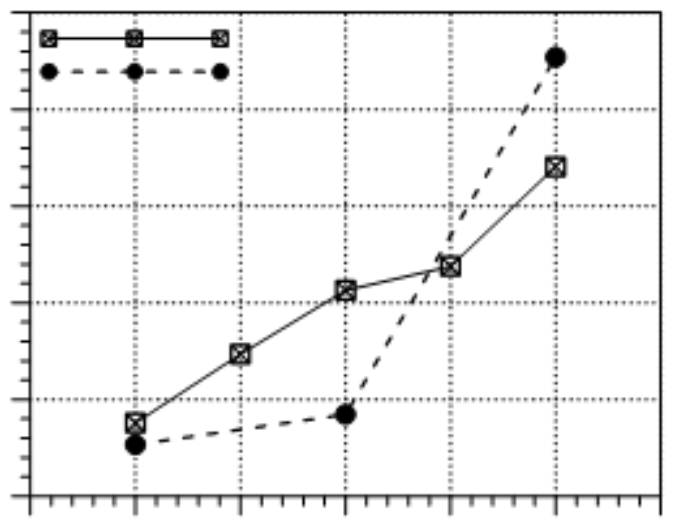

Figure 4 - Simulated and measured (FTIR) concentrations of exhaust ethane.

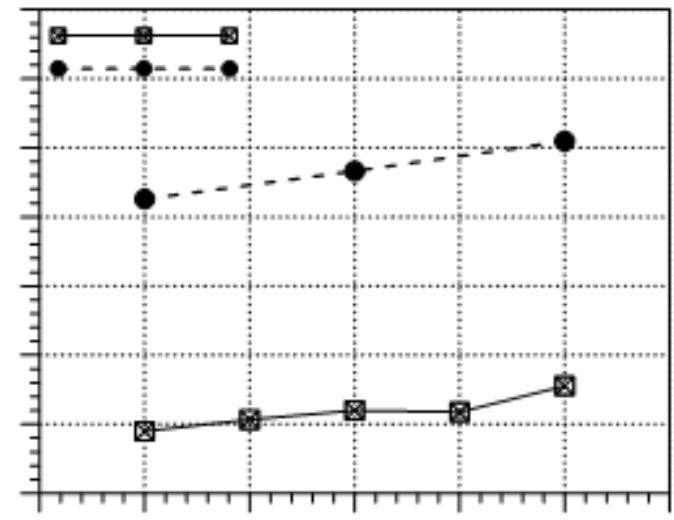

Figure 5 - Simulated and measured (FTIR) concentrations of exhaust unburned ethanol.

From Figure 5 it is observed that the simulated ethanol concentrations are very high in comparison with the measurements done by FTIR. The trend shown by exhaust unburned ethanol is clearly the same as that of acetaldehyde as in Figure 2. The studies of He et al. (2003) and Cheung et al. (2008) confirm these results: an increase in the concentration of unburned ethanol is associated with the increase of acetaldehyde concentration. With the increase of engine speed the rate of fuel mass injected into the cylinder, thus increasing the amount of unburned fuel remaining after combustion.

\section{5.}

\section{CONCLUSIONS}

The simulated values of exhaust formaldehyde, acetaldehyde and their main producers, methane, ethane and unburned ethanol, show good qualitative agreement and reasonable quantitative agreement to the measured values by FTIR analysis. The highest discrepancies found between the simulated results and the measured data was for exhaust unburned ethanol. 
The simulation model was proved to be a useful tool to estimate exhaust formaldehyde and acetaldehyde from an engine operating with ethanol as fuel. The FTIR analysis was able to measure exhaust aldehyde concentration, even the low amounts presented by formaldehyde.

\section{ACKNOWLEDGMENTS}

The authors thank CAPES, CNPq and FAPEMIG for the financial support to this project. Thanks are also due to FIAT Automobiles and AVL.

\section{REFERENCES}

AMARAL, R.A.; SODRÉ J.R. Aldehyde emissions from an ethanol-fuelled vehicle as influenced by engine geometric parameters. SAE Technical Paper 2001-01-1998. Society of Automotive Engineers, USA. 2001.

AMARAL, R.A.; SODRÉ, J.R.; Influence of engine operating parameters on aldehyde emissions from an ethanol-fuelled vehicle. Combust. Sci. Technol., v. 174, p. 153-65, 2002.

BASSHUYSEN, R.; SCHÄFER, F. Internal Combustion Engine Handbook: Basics, Components, Systems, and Perspectives. Warrendale: SAE International, 2004.

COSTA, T.O.; ZARANTE, P.H.B.; SODRÉ, J.R. Simulation of aldehyde formation in ethanol fuelled spark ignition engines, In: Sens M, Baar R, editors. Engine processes, Renningen: Expert Verlag. p. 112-122, 2013.

CHEUNG, C.S.; DI, Y.; HUANG, Z. Experimental investigation of regulated and unregulated emissions from a diesel engine fueled with ultralow-sulfur diesel fuel blended with ethanol and dodecanol. Atmos. Environ., v. 42, p. 8843-51, 2008.

DAUSTER, I. Chemical kinetics of ethanol oxidation and pyrolysis. COST - Detailed chemical models for cleaner combustion, 1st Annual Meeting, Sept. 15-16, 2010.

FRASSOLDATI, A.; CUOCI, A.; FARAVELLI, T.; NIEMANN, U.; RANZI, E.; SEISER, R.; SESHADRI, K. An experimental and kinetic modeling study of n-propanol and isopropanol combustion. Combust. Flame,. v. 157, p. 2-16, 2010.

HE, B-Q.; SHUAI, S-J.; WANG, J-X.; HE, H. The effect of ethanol blended diesel fuels on emissions from a diesel engine. Atmos. Environ. v. 37, p. 4965-71, 2003.

KEATING, E.L. Applied Combustion. New York: Marcel Dekker, 1993.

LI, J.; KAZAKOV, A.; CHAOS, M.; DRYER, F.L. Chemical kinetics of ethanol oxidation. 5th US Combustion Meeting, Paper \#C26, March 25-28, 2007.

MAGNUSSON, S.; NILSSON, C. The influence of oxygenated fuels on emissions of aldehydes and ketones from a two-stroke spark ignition engine. Fuel, v. 90, p. 1145-54, 2011. 
MARINOV, N. A detailed chemical kinetic model for high temperature ethanol oxidation. Int. J. Chem. Kinetics, v. 31, p. 183-220, 1998.

MERRIT, P.M.; ULMET, V.; McCORMICK, R.L.; MITCHELL, W.E.; BAUGMARD, K.J. Regulated and unregulated exhaust emissions comparison for three Tier II non-road diesel engines operating on ethanol-diesel blends. SAE Technical Paper 2005-01-2193., Society of Automotive Engineers, USA; 2005.

NGUYEN, H.T-H.; TAKENAKA, N.; BANDOW, H.; MAEDA, Y.; DE OLIVA, S.; BOTELHO, M.; TAVARES, T. Atmospheric alcohols and aldehydes concentrations measured in Osaka, Japan and in São Paulo, Brazil. Atmos. Environ., v. 35, p. 3075-83, 2001.

PANG, X.; UM, Y.; YUAN, J.; HE, H.; Carbonyls emission from ethanol-blended gasoline and biodiesel-ethanol-diesel used in engines. Atmos. Environ., 2008;42:1349-58.

SONG, C.; ZHAO, Z.; LIV, G.; SONG, J.; LIU, L.; ZHAO, R. Carbonyl compound emissions from a heavy-duty diesel engine fueled with diesel fuel and ethanol-diesel blend. Chemosphere, v. 79, p. 1033-39, 2010. 